\title{
Application of high-flow nasal cannula in hypoxemic patients with COVID-19: a retrospective cohort study
}

Ming $\mathrm{Hu}^{1+}$, Qiang Zhou ${ }^{2 \dagger}$, Ruiqiang Zheng ${ }^{3}$, Xuyan Li ${ }^{4}$, Jianmin Ling ${ }^{5}$, Yumei Chen ${ }^{1}$, Jing Jia ${ }^{5}$ and Cuihong Xie ${ }^{5^{*}}$

\begin{abstract}
Background: It had been shown that High-flow nasal cannula (HFNC) is an effective initial support strategy for patients with acute respiratory failure. However, the efficacy of HFNC for patients with COVID-19 has not been established. This study was performed to assess the efficacy of HFNC for patients with COVID-19 and describe early predictors of HFNC treatment success in order to develop a prediction tool that accurately identifies the need for upgrade respiratory support therapy.
\end{abstract}

Methods: We retrospectively reviewed the medical records of patients with COVID-19 treated by HFNC in respiratory wards of 2 hospitals in Wuhan between 1 January and 1 March 2020. Overall clinical outcomes, the success rate of HFNC strategy and related respiratory variables were evaluated.

Results: A total of 105 patients were analyzed. Of these, 65 patients (61.9\%) showed improved oxygenation and were successfully withdrawn from $\mathrm{HFNC}$. The $\mathrm{PaO}_{2} / \mathrm{FiO}_{2}$ ratio, $\mathrm{SpO}_{2} / \mathrm{FiO}_{2}$ ratio and $\mathrm{ROX}$ index $\left(\mathrm{SpO}_{2} / \mathrm{FiO}_{2}{ }^{*} \mathrm{RR}\right)$ at $6 \mathrm{~h}, 12 \mathrm{~h}$ and $24 \mathrm{~h}$ of HFNC initiation were closely related to the prognosis. The ROX index after $6 \mathrm{~h}$ of HFNC initiation (AUROC, 0.798) had good predictive capacity for outcomes of HFNC. In the multivariate logistic regression analysis, young age, gender of female, and lower SOFA score all have predictive value, while a ROX index greater than 5.55 at $6 \mathrm{~h}$ after initiation was significantly associated with HFNC success (OR, 17.821; 95\% Cl, 3.741-84.903 $p<0.001)$.

Conclusions: Our study indicated that HFNC was an effective way of respiratory support in the treatment of COVID19 patients. The ROX index after $6 \mathrm{~h}$ after initiating HFNC had good predictive capacity for HFNC outcomes.

Keywords: COVID-19, high-flow nasal cannula oxygen therapy, predictive factor, ROX index, respiratory support

\section{Background}

In 2020, COVID-19 swept across the world and has caused nearly 300,000 deaths. The main clinical manifestations of COVID-19 are fever, cough, and pneumonia characterized by patchy and ground glass opacities on chest imaging [1]. Severe patients can develop ARDS and progress to acute respiratory failure leading to death.

\footnotetext{
*Correspondence: xiecuihong08@163.com

${ }_{5}^{\dagger}$ Ming Hu and Qiang Zhou contributed equally to this work

${ }^{5}$ Department of Emergency and Critical Care Medicine, Tongji Hospital,

Tongji Medical College, Huazhong University of Science and Technology,

Wuhan 430030, China

Full list of author information is available at the end of the article
}

Most of the current reports found that the mortality rate of severe COVID-19 patients was high, and most of the patients died of severe hypoxemia $[2,3]$. Therefore, it is essential for respiratory support therapy in patients with severe COVID-19. At present, there is still some controversy about the respiratory support treatment of COVID19 in clinical practice. There is no clear conclusion about the indication of noninvasive respiratory support and when tracheal intubation is needed.

Although the clinical application of High-flow nasal cannula oxygen therapy (HFNC) is not long, many studies have confirmed that the use of HFNC in patients with acute respiratory failure (ARF) is safe and effective

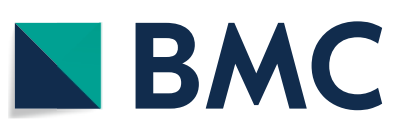

(c) The Author(s) 2020. Open Access This article is licensed under a Creative Commons Attribution 4.0 International License, which permits use, sharing, adaptation, distribution and reproduction in any medium or format, as long as you give appropriate credit to the original author(s) and the source, provide a link to the Creative Commons licence, and indicate if changes were made. The images or other third party material in this article are included in the article's Creative Commons licence, unless indicated otherwise in a credit line to the material. If material is not included in the article's Creative Commons licence and your intended use is not permitted by statutory regulation or exceeds the permitted use, you will need to obtain permission directly from the copyright holder. To view a copy of this licence, visit http://creativecommons.org/licenses/by/4.0/. The Creative Commons Public Domain Dedication waiver (http://creativeco mmons.org/publicdomain/zero/1.0/) applies to the data made available in this article, unless otherwise stated in a credit line to the data. 
$[4,5]$. One large randomized control trial comparing the effectiveness of conventional oxygen therapy, noninvasive ventilation (NIV) combined with HFNC, and HFNC alone in hypoxemic ARF demonstrated that HFNC alone reduced need for invasive mechanical ventilation (IMV) in the most severe $\left(\mathrm{PaO}_{2} / \mathrm{FiO}_{2}, \leq 200 \mathrm{~mm} \mathrm{Hg}\right)$ subgroup of patients. HFNC patients also had the higher 90-day survival rate of the entire cohort [6]. Therefore, the use of HFNC in acute respiratory failure is widely accepted, and in this outbreak of COVID-19, HFNC is also widely used in patients with severe COVID-19.

However, one of the most challenging decisions in the management of ARF patients is to decide when to move from a spontaneous breathing oxygenation therapy to IMV [7]. This is also a concern when using HFNC to treat patients with COVID-19. In this regard, although HFNC may avoid further need for IMV in some patients $[8,9]$, it may unduly delay initiation of IMV in others and worsen their outcome [10], as already evidenced for NIV [11, 12]. Therefore, to identify and describe accurate early predictors of the need for IMV in spontaneously breathing patients are of special interest. WHO has also pointed out that the oxygenation status of COVID-19 patients should be closely monitored when using HFNC in order to timely adjust the respiratory support program.

Some indicators have been shown to be useful in monitoring oxygenation status in patients with HFNC and in predicting the outcome of HFNC. Oxygen saturation index $\left(\mathrm{SpO}_{2} / \mathrm{FiO}_{2}\right)$ and respiratory rate-oxygenation index ( $\mathrm{ROX}$ index: $\mathrm{SpO}_{2} / \mathrm{FiO}_{2}{ }^{*} \mathrm{RR}$ ) have been reported to be an effective monitoring indicator in the application of HFNC [13-15]. However, it is not known whether these indicators are still applicable in COVID-19 patients.

In this study, we retrospectively analyzed the efficacy of HFNC in COVID-19 patients with hypoxic respiratory failure and the predictive values of $\mathrm{SpO}_{2} / \mathrm{FiO}_{2}$ and $\mathrm{ROX}$ index in terms of HFNC outcomes.

\section{Methods}

\section{Study design and patients}

This was retrospective observational study in which all cases were collected from respiratory wards of two hospitals in Wuhan during COVID-19 outbreak. All data were extracted from clinical records. The retrospective data analysis was approved by the ethics board of Wuhan Pulmonary Hospital and Tongji Hospital Affiliated to Tongji Medical College, Huazhong University of Science and Technology. The need for patient consent was waived because of the retrospective nature of the study.

All patients initially admitted to the respiratory department instead of ICU and treated with HFNC (AIRVO2, Fisher\&Paykel Healthcare) were included between 1 January and 1 March 2020. COVID-19 was diagnosed according to diagnosis and clinical classification criteria and treatment plan (trial version 7) of the SARS-CoV-2 coronavirus pneumonia (COVID-19) launched by the National Health Committee of the People's Republic of China. Exclusion criteria were age younger than 18 years and indication for immediate IMV [16] upon admission.

\section{Study variables}

Demographic, clinical, laboratory, management, and outcome data were obtained from the medical records. Respiratory rate and pulmonary gas exchange variables were recorded $0,2,6,12$, and 24 hours after initiation of HFNC therapy. After the first 24 hours, the same variables were recorded once daily until HFNC withdrawal. The presence of an organ failure before and during HFNC therapy was also registered. Briefly, shock was defined as need for vasopressors; renal failure was defined as increased serum creatinine $\times 1.5$ and/or urine output less than 0.5 $\mathrm{mL} / \mathrm{kg}$ per hour during 6 hours. Length of HFNC therapy and hospital stay were also investigated. The outcome measures were the success rates of HFNC and overall survival after initiating HFNC. Successful HFNC treatment was defined as HFNC withdrawal with improved oxygenation, no need for NIV and/or IMV, discharge alive. HFNC failure was defined as the need for NIV or IMV and/or death while on HFNC support.

\section{HFNC treatment strategy}

HFNC indications: Patients with $\mathrm{SpO} 2 \leq 92 \%$ and / or $R R \geq 25$ times/min under nasal tube oxygen inhalation 10L/min or mask oxygen supply. HFNC settings: The initial HFNC set the gas flow rate to $30 \mathrm{~L} / \mathrm{min}$ and the $\mathrm{FiO} 2$ of 1.0, adjust the flow rate and $\mathrm{FiO} 2$ to maintain the pulse oxygen saturation ( $\mathrm{SpO} 2)$ at $92 \%-96 \%$, and dynamically adjust it based on the blood gas analysis results.

\section{Statistical analysis}

We summarized the patients' baseline characteristics using percentages for categorical variables and medians and interquartile ranges for continuous variables. The nonparametric Mann-Whitney $U$ test was used to analyze continuous variables, and Fisher's exact test was used for categorical variables. To assess the accuracy of different variables for correctly classifying patients who would succeed or fail on HFNC, receiver operating characteristic (ROC) curves were performed, and the areas under the ROC curve (AUROC) were calculated. The optimal cutoff point of continuous variables was chosen to maximize the sum of the sensitivity and specificity. Multivariate analysis was performed using logistic regression analysis to identify independent predictive factors for HFNC success or failure. Factors with a $p$ value less than 0.10 in the univariable analyses were included in the 
multivariate model. The significance level was defined as $\mathrm{p}<0.05$. All statistical analyses were performed using SPSS, version 17.0.

\section{Results}

Clinical characteristics of included patients

During the study period, 105 patients with severe COVID-19 were treated with HFNC (Fig. 1). The demographics of the study population are shown in Table 1. The patients comprised 51 men and 54 women with a median age of 64 years. The average age of HFNC failure group was significantly higher than that of HFNC success group $(p<0.001)$. Overall, $11(10.5 \%)$ patients had a history of smoking and $60(57.1 \%)$ had comorbidities, with hypertension being the most common. Laboratory tests revealed that all patients had decreased lymphocyte counts, elevated CRP, and elevated D-dimers. The median $\mathrm{PaO}_{2} / \mathrm{FiO}_{2}$ ratio at HFNC application was 116. The HFNC failure patients had a higher PSI score, APACHE II score and SOFA score $(p<0.001, p=0.006$, $p<0.001$, respectively). Of all the patients, 65 patients (61.9\%) showed improved oxygenation and were successfully withdrawn from HFNC. Of the 40 patients for whom HFNC treatment failed, 15 were switched to NPPV, 9 were switched to IMV, and 16 continued HFNC until death (Fig. 1). The two main reasons for the last part were that some family members refused to tracheal intubation and some patients could not tolerate NPPV. The median duration of HFNC therapy and hospitalization were 6.8 days and 14 days.

\section{Impact of respiratory variables during treatment on HFNC outcome}

All patients were examined for partial pressure of oxygen in blood gas at 2, 6, 12 and 24h after HFNC, and respiratory rates, oxygen concentration, finger oxygen saturation were collected to calculate the $\mathrm{PaO}_{2} / \mathrm{FiO}_{2}$, $\mathrm{SpO}_{2} / \mathrm{FiO}_{2}, \mathrm{SpO}_{2} / \mathrm{FiO}_{2}{ }^{*} \mathrm{RR}$ at each time points. Indicators for 2 patients were collected up to $6 \mathrm{~h}$ because one patient converted to non-invasive ventilation after $6 \mathrm{~h}$ and the other died quickly after $6 \mathrm{~h}$; indicators for 4 patients were collected up to $12 \mathrm{~h}$, again because 3 patients converted to noninvasive ventilation and the other incubated. The remaining 99 patients collected indicators at all time points. HFNC success patients had higher $\mathrm{SpO}_{2} / \mathrm{FiO}_{2}, \mathrm{PaO}_{2} / \mathrm{FiO}_{2}$ and lower RR at 6,12 and $24 \mathrm{~h}$ of HFNC onset, respectively (Table 2). Significant differences were observed in ROX index after $6 \mathrm{~h}$ of HFNC treatment between success and failure HFNC patients (Table 2). The differences increased throughout the study period. The $\mathrm{SpO}_{2} / \mathrm{FiO}_{2}, \mathrm{PaO}_{2} / \mathrm{FiO}_{2}$ and ROX index had a same trend, that is, they gradually increased in the HFNC success group, and gradually declined in the HFNC failure group. Their accuracy to predict success of HFNC was assessed by calculating the AUROC (Table 3). None of the variables analyzed

Table 1 Characteristics of patients with severe COVID-19 treated with HFNC

\begin{tabular}{|c|c|c|c|c|}
\hline \multirow[t]{2}{*}{ Characteristics } & \multirow[t]{2}{*}{ All patients $(n=105)$} & \multicolumn{2}{|c|}{ Outcome of HFNC treatment } & \multirow[t]{2}{*}{$p$ value } \\
\hline & & Success $(n=65)$ & Failure $(n=40)$ & \\
\hline \multicolumn{5}{|l|}{ Baseline characteristics } \\
\hline Age (years) & $64.0 \pm 11.3$ & $59.5 \pm 10.9$ & $71.3 \pm 7.6$ & $<0.001$ \\
\hline Sex, male & $51(48.6 \%)$ & $26(40.0 \%)$ & $25(62.5 \%)$ & 0.025 \\
\hline Smoking & $11(10.5 \%)$ & $7(10.8 \%)$ & $4(10.0 \%)$ & 0.901 \\
\hline Comorbidities & $60(57.1 \%)$ & $35(53.8 \%)$ & $25(62.5 \%)$ & 0.384 \\
\hline \multicolumn{5}{|l|}{ Lab tests at admission } \\
\hline $\operatorname{LYM}\left(\times 10^{9} / \mathrm{L} ;\right.$ normal range $\left.1.1-3.2\right)$ & $0.63(0.43-0.80)$ & $0.62(0.49-0.79)$ & $0.70(0.36-0.80)$ & 0.777 \\
\hline D-D (ug/ml; normal range 0.0-0.5) & $0.67(0.42-4.19)$ & $0.62(0.42-1.78)$ & $1.04(0.46-5.00)$ & 0.056 \\
\hline CRP (mg/L; normal range 0.0-5.0) & $46.8(28.2-83.5)$ & $45.6(30.4-83.5)$ & $39.3(23.4-85.4)$ & 0.946 \\
\hline Time from onset of symptom to hospital admission (days) & $10.0(7.0-12.0)$ & $10.0(7.0-12.0)$ & $9.0(5.0-12.0)$ & 0.373 \\
\hline Time from admission to HFNC application (days) & $1.0(0.0-2.0)$ & $1.0(0.0-2.0)$ & $1.0(1.0-2.0)$ & 0.129 \\
\hline $\mathrm{PaO}_{2} / \mathrm{FiO}_{2}$ at $\mathrm{HFNC}$ application & $116.0(102.1-132.0)$ & $116.0(102.7-128.0)$ & $112.8(100.5-138.5)$ & 0.722 \\
\hline PSI & $76.0(54.0-82.5)$ & $62.0(49.0-80.0)$ & $81.5(78.0-97.5)$ & $<0.001$ \\
\hline APACHE $\|$ of $24 \mathrm{~h}$ admission & $8.0(6.5-10.0)$ & $8.0(5.0-10.0)$ & $9.0(8.0-10.8)$ & 0.006 \\
\hline SOFA admission & $3.0(3.0-4.0)$ & $3.0(3.0-3.0)$ & $4.0(3.0-5.0)$ & $<0.001$ \\
\hline Length of HFNC (days) & $5.0(2.5-9.0)$ & $6.0(3.5-8.5)$ & $3.0(2.0-11.0)$ & 0.115 \\
\hline Length of hospital stay (days) & $14.0(10.5-19.0)$ & $14.0(12.0-20.0)$ & $11.5(7.0-14.0)$ & 0.001 \\
\hline
\end{tabular}

Each parameter is expressed as number (percentage) or median (interquartile range). Parameters in each group were compared using Fisher's exact test or the MannWhitney U test. HFNC, high-flow nasal cannula oxygen therapy; LYM, lymphocyte number; D-D, D-dimer; CRP, C-reaction protein 
Screened for patients with COVID-19 admitted to respiratory wards $(n=643)$

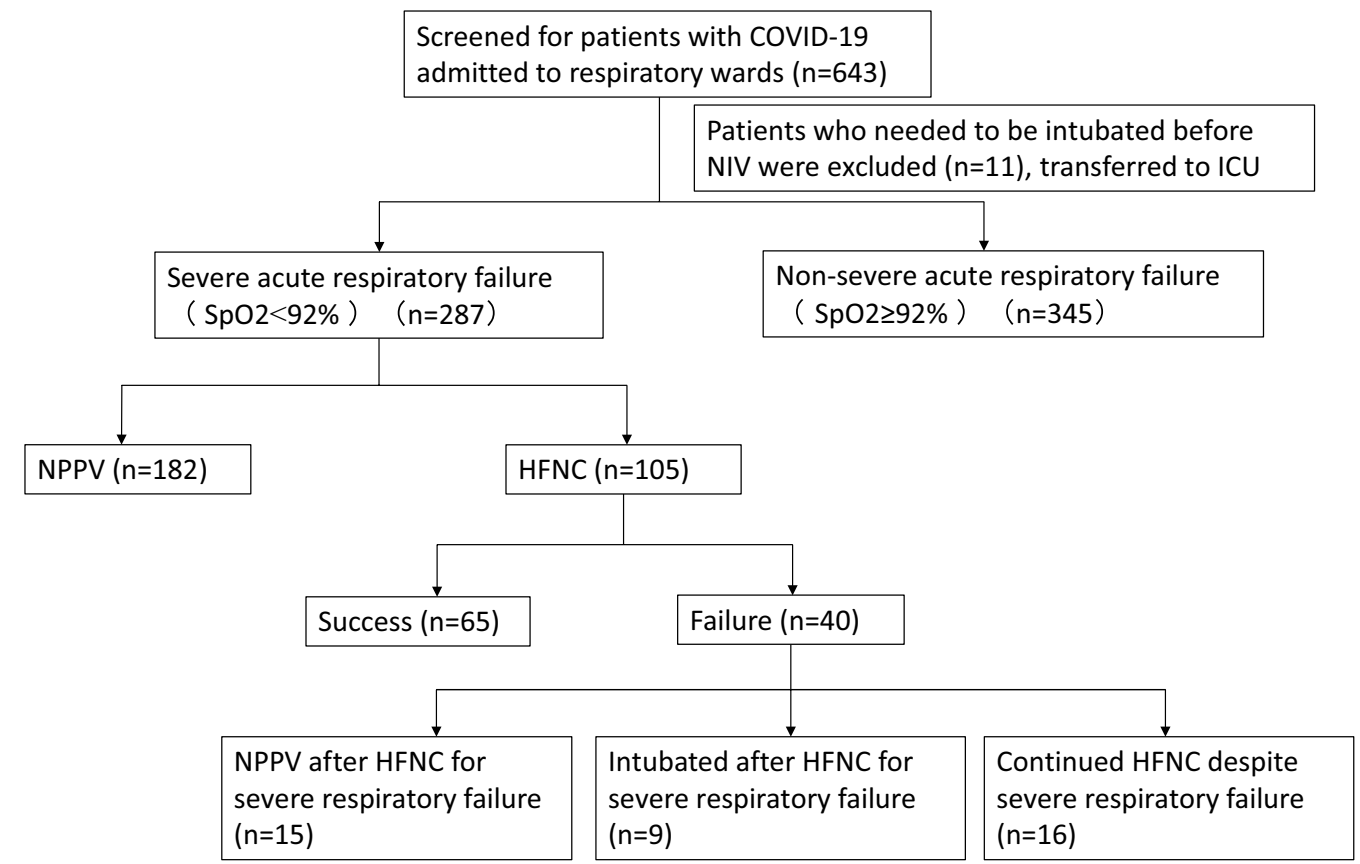

Fig. 1 Diagram of patients flow in this study. Non-invasive ventilation, NIV; Non-invasive positive pressure ventilation, NPPV; HFNC, high-flow nasal cannula oxygen therapy

Table 2 Changes in respiratory variables during HFNC

\begin{tabular}{lcccr}
\hline Variables & Time (h) & HFNC success & HFNC failure & \multicolumn{1}{l}{$\boldsymbol{P}$} \\
\hline $\mathrm{RR}$ & 2 & $24(22-26)$ & $25(23-27)$ & 0.138 \\
& 6 & $22(21-24)$ & $24(23-26)$ & 0.001 \\
& 12 & $22(20-25)$ & $25(24-25)$ & 0.002 \\
& 24 & $21(20-23)$ & $25(25-28)$ & $<0.001$ \\
$\mathrm{SpO}_{2} / \mathrm{FiO}_{2}$ & 2 & $153.2(135.6-194.9)$ & $158.3(139.8-170.0)$ & 0.157 \\
& 6 & $158.6(135.3-215.3)$ & $123.8(116.7-157.9)$ & $<0.001$ \\
& 12 & $179.6(136.1-206.5)$ & $127.0(115.3-161.7)$ & $<0.001$ \\
& 24 & $182.7(142.8-202.1)$ & $126.4(116.0-153.8)$ & $<0.001$ \\
$\mathrm{PaO}_{2} / \mathrm{FiO}_{2}$ & 2 & $116.7(93.8-143.8)$ & $111.1(100.0-125.0)$ & 0.141 \\
& 6 & $115.4(100.8-164.3)$ & $95.3(83.5-120.3)$ & $<0.001$ \\
& 12 & $130.0(104.6-168.8)$ & $90.7(76.9-106.3)$ & $<0.001$ \\
& 24 & $145.0(107.2-167.3)$ & $85.2(72.9-110.9)$ & $<0.001$ \\
& 2 & $6.8(5.6-7.8)$ & $6.4(4.9-7.6)$ & 0.074 \\
$\mathrm{ROX} \mathrm{index}$ & 6 & $6.7(5.9-9.5)$ & $5.0(4.6-6.5)$ & $<0.001$ \\
& 12 & $7.9(6.1-9.1)$ & $5.0(4.4-7.3)$ & $<0.001$ \\
& 24 & $7.8(6.6-10.0)$ & $4.8(4.4-6.0)$ & $<0.001$ \\
\hline
\end{tabular}

Each parameter is expressed as median (interquartile range). Parameters in each group were compared using the Mann-Whitney $\mathrm{U}$ test. $R R$ respiratory rate, $\mathrm{SpO}_{2}$ pulse oxygen saturation, $\mathrm{FiO}_{2}$ fraction of inspired oxygen, $\mathrm{PaO}_{2}$ arterial partial pressure of oxygen, ROX index Respiratory rate-oxygenation index

at $2 \mathrm{~h}$ after HFNC had good predictive capacity for outcomes of HFNC (AUROC, <0.7). After $6 \mathrm{~h}$ of HFNC treatment, $\quad \mathrm{SpO}_{2} / \mathrm{FiO}_{2}, \quad \mathrm{PaO}_{2} / \mathrm{FiO}_{2}$ and $\mathrm{ROX}$ index
Table 3 Decision accuracy of the outcome of high-flow nasal cannula oxygen therapy

\begin{tabular}{|c|c|c|c|}
\hline & Variable & AUROC & $95 \% \mathrm{Cl}$ \\
\hline \multirow[t]{3}{*}{$2 \mathrm{~h}$} & $\mathrm{SpO}_{2} / \mathrm{FiO}_{2}$ & 0.536 & $0.421-0.651$ \\
\hline & $\mathrm{PaO}_{2} / \mathrm{FiO}_{2}$ & 0.540 & $0.426-0.654$ \\
\hline & ROX index & 0.560 & $0.444-0.677$ \\
\hline \multirow[t]{3}{*}{$6 \mathrm{~h}$} & $\mathrm{SpO}_{2} / \mathrm{FiO}_{2}$ & 0.786 & $0.693-0.878$ \\
\hline & $\mathrm{PaO}_{2} / \mathrm{FiO}_{2}$ & 0.749 & $0.648-0.850$ \\
\hline & ROX index & 0.798 & $0.703-0.893$ \\
\hline \multirow[t]{3}{*}{$12 \mathrm{~h}$} & $\mathrm{SpO}_{2} / \mathrm{FiO}_{2}$ & 0.805 & $0.717-0.892$ \\
\hline & $\mathrm{PaO}_{2} / \mathrm{FiO}_{2}$ & 0.832 & $0.751-0.913$ \\
\hline & ROX index & 0.820 & $0.727-0.913$ \\
\hline \multirow[t]{3}{*}{$24 \mathrm{~h}$} & $\mathrm{SpO}_{2} / \mathrm{FiO}_{2}$ & 0.818 & $0.732-0.903$ \\
\hline & $\mathrm{PaO}_{2} / \mathrm{FiO}_{2}$ & 0.855 & $0.780-0.930$ \\
\hline & ROX index & 0.874 & $0.799-0.949$ \\
\hline
\end{tabular}

demonstrated a good prediction accuracy (AUROC, $0.786,0.749,0.798$, respectively). Using the ROC curve, the best cutoff point for the ROX index at $6 \mathrm{~h}$ was estimated to be 5.55 . A ROX index greater than 5.55 at $6 \mathrm{~h}$ after HFNC onset has a sensitivity of $61.1 \%$, a specificity of $84.6 \%$, a positive predictive value of $68.8 \%$, a negative predictive value of $79.8 \%$. 
Univariate and multivariate analyses of predictive factors for HFNC outcome

In the univariate analysis, age, gender, PSI, APACHE II and SOFA were relevant influencing factors for the HFNC success (Table 4). More significantly, a ROX index greater than 5.55 (OR, 8.643; CI, 3.342-22.354; $p<0.001$ ) at $6 \mathrm{~h}$ of HFNC application, was significant predictors of HFNC outcome. However, incorporating all the indicators related to HFNC success in univariate analysis into multivariate analysis found that young age, gender of female, SOFA and ROX index were independent prognostic factors of HFNC success. Among these indicators, the ROX index greater than 5.55 at $6 \mathrm{~h}$ of HFNC application is the most relevant predictor of HFNC success (OR, 17.821; 95\% CI, 3.741-84.903; $p<0.001)$.

\section{Discussion}

The current study was conducted to evaluate the efficacy of HFNC in COVID-19 patients with hypoxic respiratory failure. Our results showed that HFNC was an effective treatment for these patients, and approximately $61.9 \%$ of patients showed improved oxygenation

Table 4 Univariate and multivariate analyses of predictive factors for successful HFNC

\begin{tabular}{|c|c|c|c|}
\hline Variable & Odds ratio & $95 \% \mathrm{Cl}$ & $p$ value \\
\hline \multicolumn{4}{|c|}{ Univariate analysis of predictive factors of the outcome of HFNC } \\
\hline Age, years & 0.871 & $0.819-0.926$ & $<0.001$ \\
\hline Sex, male & 0.400 & $0.178-0.899$ & 0.027 \\
\hline Comorbidities & 0.700 & $0.313-1.565$ & 0.385 \\
\hline Smoking, current or former & 1.086 & $0.297-3.973$ & 0.901 \\
\hline $\begin{array}{l}\text { LYM }\left(\times 10^{9} / \mathrm{L} ; \text { normal range }\right. \\
1.1-3.2)\end{array}$ & 1.045 & $0.235-4.657$ & 0.954 \\
\hline $\begin{array}{l}\text { D-D (ug/ml; normal range } \\
0.0-0.5)\end{array}$ & 1.001 & $0.947-1.058$ & 0.974 \\
\hline $\begin{array}{l}\text { CRP (mg/L; normal range } \\
0.0-5.0)\end{array}$ & 0.999 & $0.988-1.011$ & 0.922 \\
\hline $\mathrm{PaO}_{2} / \mathrm{FiO}_{2}$ at $\mathrm{HFNC}$ application & 1.002 & $0.985-1.018$ & 0.830 \\
\hline PSI & 0.931 & $0.903-0.960$ & $<0.001$ \\
\hline APACHE-II & 0.822 & $0.710-0.951$ & 0.008 \\
\hline SOFA & 0.501 & $0.338-0.744$ & 0.001 \\
\hline 6h ROX index $>5.55$, yes & 8.643 & $3.342-22.354$ & $<0.001$ \\
\hline \multicolumn{4}{|c|}{ Multivariate analysis of predictive factors of the outcome of HFNC } \\
\hline Age, years & 0.837 & $0.745-0.940$ & 0.003 \\
\hline Sex, male & 0.172 & $0.038-0.790$ & 0.024 \\
\hline PSI & 1.004 & $0.939-1.074$ & 0.903 \\
\hline APACHE-II & 1.166 & $0.858-1.585$ & 0.326 \\
\hline SOFA & 0.389 & $0.203-0.745$ & 0.004 \\
\hline $6 \mathrm{~h}$ ROX index $>5.55$, yes & 17.821 & $3.741-84.903$ & $<0.001$ \\
\hline
\end{tabular}

HFNC high-flow nasal cannula oxygen therapy, LYM lymphocyte number, $D-D$, D-dimer, CRP c-reaction protein, PSI pneumonia severity index, APACHE-Il Acute Physiology and Chronic Health Evaluation II, SOFA Sepsis-related Organ failure Assessment, ROX index Respiratory rate-oxygenation index and were able to successfully withdraw from HFNC. Furthermore, The $\mathrm{PaO}_{2} / \mathrm{FiO}_{2}, \mathrm{SpO}_{2} / \mathrm{FiO}_{2}$ and $\mathrm{ROX}$ index after $6 \mathrm{~h}$ HFNC application can predict the success of HFNC application. The ROX index at $6 \mathrm{~h}$ HFNC application has best predictive value when considering both statistical and clinical significance.

A typical characteristic of the severe acute respiratory syndrome-related coronavirus-2 (SARS-CoV-2) infected patient is pneumonia, now termed as COVID-19. Generally, the patients showed the acute respiratory infection symptoms, with some that quickly developed acute respiratory failure and even died of refractory hypoxemia $[17,18]$. Therefore, respiratory support, especially oxygen therapy, is very important in the treatment of severe COVID-19. However, there is still controversy about whether invasive ventilator treatment or non-invasive ventilator treatment is better for COVID-19 patients, especially there are obvious complications of infection in the late stage of intubation due to the long course of the disease [19]. As a new method of oxygen therapy, HFNC can effectively improve oxygenation, reduce the probability of invasive and non-invasive mechanical ventilation. HFNC provides sufficiently heated and humidified oxygen to relieve nasal cavity irritation. It has obvious advantages over traditional oxygen therapy [20-22]. Previous studies have found that HFNC can be used in ICU patients with acute hypoxemic respiratory failure [4, 23]. HFNC has been reported to be superior to NPPV in terms of both mortality and comfort [24]. However, in COVID-19, pulmonary lesions often begin with interstitial exudation and gradually progress to large consolidation, and lung compliance significantly decreases. In addition to the long course of disease, ventilator-related complications, such as barotrauma and ventilator-related infections, are prone to occur in the mid-term after IMV treatment. Therefore, the use of HFNC in COVID-19 has certain advantages. More than half of the patients in our study eventually successfully weaned from the ventilator, suggesting that HFNC is a treatment worth considering for COVID-19. In addition, we found that although there was no significant difference in the oxygenation index between HFNC success group and HFNC failure group at the beginning of HFNC treatment, PSI, APACHII and SOFA were significantly lower in the survival group than that in the death group, which suggesting that the patients with successful HFNC treatment were relatively mild. Accordingly, multivariate regression analysis found that young age, gender of female, and lower SOFA were independent prognostic factors of the outcome of HFNC. It means that the treatment strategy of HFNC needs to be determined in the context of the overall severity of the patients with COVID-19. 
During the treatment of HFNC, how to judge the therapeutic effect, when HFNC should continue, and when HFNC needs to be converted to IMV or NPPV have always been a concern. In particular, studies have found that delayed intubation in HFNC may lead to increased mortality [25]. Therefore, how to determine the poor therapeutic effect of HFNC in the early stage and timely change the ventilator support mode is the most critical issue in the use of HFNC. $\mathrm{PaO}_{2} / \mathrm{FiO}_{2}$ has been the gold standard for judging patients' oxygenation status. In our study, we also found that the level of $\mathrm{PaO}_{2} / \mathrm{FiO}_{2}$ after $6 \mathrm{~h}$ of HFNC was significantly correlated with the outcome of treatment (AUROC > 0.75). However, the acquisition of $\mathrm{PaO}_{2} / \mathrm{FiO}_{2}$ needs to draw patients' arterial blood regularly, which is not easy to implement sometimes.

The relationship between $\mathrm{SpO}_{2} / \mathrm{FiO}_{2}$ and $\mathrm{PaO}_{2} / \mathrm{FiO}_{2}$ is linear and can be described by the following equation: $\mathrm{SpO}_{2} / \mathrm{FiO}_{2}=64+0.84 *\left(\mathrm{PaO}_{2} / \mathrm{FiO}_{2}\right)$ [26]. Studies have found that ARDS patients diagnosed by $\mathrm{SpO}_{2} /$ $\mathrm{FiO}_{2}$ and $\mathrm{PaO}_{2} / \mathrm{FiO}_{2}$ have similar clinical characteristics and prognosis [27]. $\mathrm{SpO}_{2} / \mathrm{FiO}_{2}$ and $\mathrm{PaO}_{2} / \mathrm{FiO}_{2}$ correlated well in our study, and $\mathrm{SpO}_{2} / \mathrm{FiO}_{2}$ was clearly correlated with prognosis after $6 \mathrm{~h}$ of HFNC application (AUROC $\approx 0.8$ ). ROX index is an index of the effect of respiratory rate added to $\mathrm{SpO}_{2} / \mathrm{FiO}_{2}$. From the results of this study in COVID-19 patients with respiratory failure, the predicted value of the ROX index is relatively higher than the $\mathrm{SpO}_{2} / \mathrm{FiO}_{2}$. Oriol et al. [28] have reported ROX index greater than 4.88 after $12 \mathrm{~h}$ of HFNC application was an independent predictor of HFNC success. Although the AUROC of $24 \mathrm{~h}$ ROX index is larger than that of $6 \mathrm{~h}$ ROX index in present study, the $6 \mathrm{~h}$ ROX index is a more suitable predictor of HFNC success considering both statistical and clinical significance. A ROX index greater than 5.55 at $6 \mathrm{~h}$ after HFNC onset has a relatively low sensitivity $(61.1 \%)$ and a relatively high specificity $(84.6 \%)$. It is helpful for clinical patients to avoid delayed intubation, which has been proved to be unfavorable for prognosis. In present study, most of the intubations occurred on 2-7 days rather than within $24 \mathrm{~h}$ HFNC treatment. The most likely reason is that, the patient population included in this study is non-ICU patients, excluding patients with respiratory failure who needed endotracheal intubation during initial oxygen therapy. This also implies that delayed intubation may be common in the real world of COVID-19, which may be related to poor prognosis.

This study had some mentionable limitations. First, this was a retrospective study. We did not predefine how to manage the HFNC. The transition to NPPV or IMV was decided by the attending physicians. Different physicians have different opinions on the point to switch to NPPV or IMV. However, this study can reflect on how the HFNC has been used in the real world among the COVID-19 patients. Second, the number of cases is not large enough. Only 105 patients were enrolled in this study. This is all COVID-19 patients who met our standard treated in two hospitals during this period. We hope to provide a true picture of HFNC treatment of COVID-19 for future reference when using HFNC to treat COVID-19 patients with hypoxic respiratory failure.

\section{Conclusion}

Our study described the use of HFNC during the COVID-19 Outbreak and indicated that HFNC was an effective way of respiratory support in the treatment of severe COVID-19. Close monitoring of respiratory parameters is very important and will determine the next treatment strategy. The ROX index after $6 \mathrm{~h}$ of HFNC application had good predictive capacity for HFNC outcomes.

\section{Abbreviations}

COVID-19: 2019 novel coronavirus disease; HFNC: High-flow nasal cannula oxygen therapy; NPPV: Non-invasive positive pressure ventilation; NIV: Noninvasive ventilation; IMV: Invasive mechanical ventilation; ROX index: Respiratory rate-oxygenation index.

\section{Acknowledgements}

Not applicable.

\section{Authors' contributions}

$\mathrm{MH}$ and $\mathrm{QZ}$ participate in research design, the acquisition of data, the writing of the manuscript, and the performance of the research. $R Z, X L, J L, Y C, J J$ and CX, contributed to the acquisition of data, interpretations of data, QZ and CX participate in preparation of the manuscript and final revision. All authors read and approved the final revision of the manuscript.

\section{Funding}

Not applicable.

\section{Availability of data and materials}

The datasets used and/or analyzed during the current study are available from the corresponding author on reasonable request.

\section{Ethics approval and consent to participate}

The retrospective data analysis was approved by the ethics board of Wuhan Pulmonary Hospital and Tongji Hospital Affiliated to Tongji Medical College, Huazhong University of Science and Technology. The need for patient consent was waived because of the retrospective nature of the study.

\section{Consent for publication}

Not applicable.

\section{Competing interests}

The authors declare that they have no competing interests.

\section{Author details}

${ }^{1}$ Department of Critical Care Medicine, Wuhan Pulmonary Hospital, Wuhan 430030, China. ${ }^{2}$ Division of Cardiology, Department of Internal Medicine, Tongji Hospital, Tongji Medical College, Huazhong University of Science and Technology, Wuhan 430030, China. ${ }^{3}$ Department of Critical Care Medicine, Northern Jiangsu People's Hospital, Yangzhou 225001, Jiangsu Province, China. ${ }^{4}$ Department of Respiratory and Critical Care Medicine, Beijing Institute of Respiratory Medicine, Beijing Chao-Yang Hospital, Capital Medical University, Beijing 100020, China. ${ }^{5}$ Department of Emergency and Critical Care Medicine, Tongji Hospital, Tongji Medical College, Huazhong University of Science and Technology, Wuhan 430030, China. 
Received: 14 May 2020 Accepted: 22 November 2020

Published online: 24 December 2020

\section{References}

1. Huang C, Wang Y, Li X, Ren L, Zhao J, Hu Y, et al. Clinical features of patients infected with 2019 novel coronavirus in Wuhan, China. Lancet. 2020;395(10223):497-506.

2. Yang $X, Y u Y, X u J$, Shu $H$, Xia J, Liu H, et al. Clinical course and outcomes of critically ill patients with SARS-CoV-2 pneumonia in Wuhan, China: a single-centered, retrospective, observational study. Lancet Respir Med. 2020. https://doi.org/10.1016/S2213-2600(20)30079-5.

3. Zhou F, Yu T, Du R, Fan G, Liu Y, Liu Z, et al. Clinical course and risk factors for mortality of adult inpatients with COVID-19 in Wuhan, China: a retrospective cohort study. Lancet. 2020;395(10229):1054-62.

4. Frat J-P, Thille AW, Mercat A, Girault C, Ragot S, Perbet S, et al. High-Flow Oxygen through Nasal Cannula in Acute Hypoxemic Respiratory Failure N Engl J Med. 2015;372(23):2185-96.

5. Sztrymf B, Messika J, Mayot T, Lenglet H, Dreyfuss D, Ricard J-D. Impact of high-flow nasal cannula oxygen therapy on intensive care unit patients with acute respiratory failure: a prospective observational study. J Crit Care. 2012;27(3):324 e9-13.

6. Raghu G, Collard HR, Egan JJ, Martinez FJ, Behr J, Brown KK, et al. An official ATS/ERS/JRS/ALAT statement: idiopathic pulmonary fibrosis: evidence-based guidelines for diagnosis and management. Am J Respir Crit Care Med. 2011;183(6):788-824.

7. Tobin MJ, Laghi F, Jubran A. Ventilatory failure, ventilator support, and ventilator weaning. Compr Physiol. 2012;2(4):2871-921.

8. Roca O, Riera J, Torres F, Masclans JR. High-flow oxygen therapy in acute respiratory failure. Respir Care. 2010;55(4):408-13.

9. Roca O, de Acilu MG, Caralt B, Sacanell J, Masclans JR. Humidified high flow nasal cannula supportive therapy improves outcomes in lung transplant recipients readmitted to the intensive care unit because of acute respiratory failure. Transplan-tation 2015; 99(5):1092-8.

10. Kang BJ, Koh Y, Lim C-M, Huh JW, Baek S, Han M, et al. Failure of high-flow nasal can-nula therapy may delay intubation and increase mortality. Intensive Care Med. 2015;41(4):623-32.

11. Agarwal R, Aggarwal AN, Gupta D. Role of noninvasive ventilation in acute lung in-jury/acute respiratory distress syndrome: a proportion meta-analysis. Respir Care. 2010;55(12):1653-60.

12. Esteban A, Frutos-Vivar F, Ferguson ND, Arabi Y, Apezteguía C, González $M$, et al. Noninvasive positive-pressure ventilation for respiratory failure after extubation. N Engl J Med. 2004;350(24):2452-60.

13. Kim BK, Kim S, Kim CY, Cha J, Lee YS, Ko Y, et al. Factors Associated With Failure of High-Flow Nasal Cannula. Respir Care. 2020. doi:https://doi. org/10.4187/respcare.07403.

14. Spinelli E, Roca O, Mauri T. Dynamic assessment of the ROX index during nasal high flow for early identification of non-responders. J Crit Care. 2019. Doi:https://doi.org/10.1016/j.jcrc.2019.08.013.

15. Karim HMR, Zaccagnini M, Esquinas AM. Acute increase in nasal high flow support and ROX index stability: Our insights in response to Mauri T et al. J Crit Care. 2019. Doi:https://doi.org/10.1016/j.jcrc.2019.08.015.
16. Brochard L, Mancebo J, Wysocki M, Lofaso F, Conti G, Rauss A, et al. Noninvasive ven-tilation for acute exacerbations of chronic obstructive pulmonary disease. N Engl J Med. 1995;333(13):817-22.

17. Xu Z, Shi L, Wang Y, Zhang J, Huang L, Zhang C, et al. Pathological findings of COVID-19 associated with acute respiratory distress syndrome. Lancet Respir Med. 2020;8(4):420-2.

18. Wang D, Hu B, Hu C, Zhu F, Liu X, Zhang J, et al. Clinical Characteristics of 138 Hospitalized Patients With 2019 Novel Coronavirus-Infected Pneumonia in Wuhan, China. JAMA. 2020. Doi:https://doi.org/10.1001/ jama.2020.1585.

19. Ling L, So C, Shum HP, Chan PKS, Lai CKC, Kandamby DH, et al. Critically ill patients with COVID-19 in Hong Kong: a multicentre retrospective observational cohort study. Crit Care Resusc. 2020. [Epub ahead of print] PMID: 32248675

20. Koga Y, Kaneda K, Fujii N, Tanaka R, Miyauchi T, Fujita M, et al. Comparison of high-flow nasal cannula oxygen therapy and non-invasive ventilation as first-line therapy in respiratory failure: a multicenter retrospective study. Acute Med Surg. 2019;7(1):e461. https://doi.org/10.1002/ams2.461.

21. Rochwerg B, Granton D, Wang DX, Helviz Y, Einav S, Frat JP, et al. High flow nasal cannula compared with conventional oxygen therapy for acute hypoxemic respiratory failure: a systematic review and meta-analysis. Intensive Care Med. 2019;45:563-72.

22. Tinelli V, Cabrini L, Fominskiy E, Franchini S, Ferrante L, Ball L, et al. High flow nasal cannula oxygen vs. conventional oxygen therapy and noninvasive ventilation in emergency department patients: a systematic review and meta-analysis. J Emerg Med. 2019;57:322-8.

23. Azoulay E, Lemiale V, Mokart D, Nseir S, Argaud L, Pène F, et al. Effect of high-flow nasal oxygen vs standard oxygen on 28-day mortality in immunocompromised patients with acute respiratory failure: the HIGH randomized clinical trial. JAMA. 2018;320:2099-107.

24. Tu G, He H, Yin K, Ju M, Zheng Y, Zhu D, et al. High-flow nasal cannula versus noninvasive ventilation for treatment of acute hypoxemic respiratory failure in renal transplant recipients. Transplant Proc. 2017:49:1325-30.

25. Kang BJ, Koh Y, Lim CM, Huh JW, Baek S, Han M, et al. Failure of high-flow nasal cannula therapy may delay intubation and increase mortality. Intensive Care Med. 2015;41:623-32.

26. DesPrez K, McNeil JB, Wang C, Bastarache JA, Shaver CM, Ware LB. Oxygenation Saturation Index Predicts Clinical Outcomes in ARDS. Chest 2017; 152(6):1151-58.

27. Rice TW, Wheeler AP, Bernard GR, Hayden DL, Schoenfeld DA, Ware LB. Comparison of the $\mathrm{SpO}_{2} / \mathrm{FIO}_{2}$ ratio and the $\mathrm{PaO}_{2} / \mathrm{FIO}_{2}$ ratio in patients with acute lung injury or ARDS. Chest. 2007:132(2):410-7.

28. Roca O, Messika J, Caralt B, García-de-Acilu M, Sztrymf B, Ricard JD, et al. Predicting success of high-flow nasal cannula in pneumonia patients with hypoxemic respiratory failure: The utility of the ROX index. J Crit Care. 2016;35:200-5.

\section{Publisher's Note}

Springer Nature remains neutral with regard to jurisdictional claims in published maps and institutional affiliations.

Ready to submit your research? Choose BMC and benefit from

- fast, convenient online submission

- thorough peer review by experienced researchers in your field

- rapid publication on acceptance

- support for research data, including large and complex data types

- gold Open Access which fosters wider collaboration and increased citations

- maximum visibility for your research: over 100M website views per year

At $\mathrm{BMC}$, research is always in progress.

Learn more biomedcentral.com/submissions 